УДК 371.13

DOI: 10.37026/2520-6427-2021-105-1-115-119

\section{Оксана МАРЧУК,}

доктор педагогічних наук,

доиент, професор кафедри педагогіки

ПВНЗ «Міжнародний економіко-гуманітарний

університет імені академіка Степана Дем'янчука», м. Рівне, Украӥна

ORCID: 0000-0002-2922-285X

e-mail:oxanna442@ukr.net

\section{Лілія МЕЛЬНИЧУК,}

кандидат педагогічних наук, дочент,

дочент кафедри педагогіки

ПВНЗ «Міжнародний економіко-гуманітарний

університет імені академіка Степана Дем'янчука»,

м. Рівне, Украӥна

ORCID: 0000-0001-8307-7932

e-mail: lilya1154@ukr.net

Маргарита ШКАБАРІНА,

кандидат педагогічних наук,

доцент кафедри украӥнської мови та літератури,

ПВНЗ «Міжнародний економіко-гуманітарний

університет імені академіка Степана Дем'янчука»,

м. Рівне, Україна

ORCID: 0000-0002-9818-9723

e-mail:shkabarina@ukr.net

\title{
ПРОФЕСІЙНА ПІДГОТОВКА МАЙБУТНІХ ПЕДАГОГІЧНИХ ПРАЦІВНИКІВ У СФЕРІ ДОШКІЛЬНОЇ ОСВІТИ ДО РОБОТИ 3 ДІТЬМИ У РІЗНОВІКОВІЙ ГРУПІ
}

\begin{abstract}
Анотація. У статті розроблено модель підготовки майбутніх педагогічних працівників у сфері дошкільної освіти до роботи з дітьми у різновіковій групі. Обгрунтовано важливість підготовки майбутніх вихователів до роботи з дошкільниками в умовах різновікової групи. Проаналізовано праці сучасних науковців з досліджуваної проблеми. Пояснено, що поняття «моделювання» $\epsilon$ широким і недостатньо конкретизованим. Встановлено, щзо принциии моделювання і планування специифічно відображають, з одного боку, принциипи управління, а 3 іншого - особливості планування як попередньої стадіi та функиії проиесу управління. Розроблена авторська модель професійної підготовки майбутніх вихователів до роботи у різновікових групах базується на ідеях
\end{abstract}

особистісно-діяльнісного, ресурсного та інтеграцийного підходів до педагогічної діяльності студентів. Акиентовано увагу на необхідності побудови освітнього процесу на основі інтеграції навчальних дисчиплін із дисииплінами методично-практичної підготовки, необхідних для подальшої організачійної та творчої педагогічної діяльності майбутніх вихователів. Виокремлено три етапи підготовки майбутніх педагогічних прачівників у сфері дошкільної освіти. Представлено шляхи вдосконалення фахової підготовки майбутніх вихователів до роботи із дошкільниками в групах, де навчаються діти різного віку.

Ключові слова: моделювання, фахова підготовка, дошкільна освіта, різновікові групи, прочес виховання.

\section{Oksana MARCHUK,}

Doctor of Pedagogical Sciences,

Associate Professor, Professor

of the Department of Pedagogy, Academician Stepan

Demianchuk International University

of Economics and Humanities,

Rivne, Ukraine

ORCID: 0000-0002-2922-285X

e-mail: oxanna442@ukr.net

\section{Lilia MELNYCHUK,}

Candidate of Pedagogical Sciences,

Associate Professor, Associate Professor

of the Department of Pedagogy, Academician Stepan

Demianchuk International University

of Economics and Humanities,

Rivne, Ukraine

ORCID: 0000-0001-8307-7932

e-mail:lilya1154@ukr.net 
Margarita SHKABARINA,

Candidate of Pedagogical Sciences,

Associate Professor of the Department of Ukrainian

Language and Literature, Academician Stepan

Demianchuk International University

of Economics and Humanities,

Rivne, Ukraine

ORCID: 0000-0002-9818-9723

e-mail: shkabarina@ukr.net

\section{PROFESSIONAL TRAINING OF THE FUTURE PEDAGOGICAL WORKERS IN THE FIELD OF PRESCHOOL EDUCATION FOR WORKING WITH CHILDREN IN THE DIFFERENT AGE GROUP}

\begin{abstract}
In the article the model of training future preschool education specialists to work with children in different age groups is representatived. The importance of preparing future educators to work with preschoolers in different age groups is substantiated. It is explained that today the process of consolidation of educational institutions has place and, accordingly, the unification of groups in preschool institutions is so popular. In rural areas there are mostly groups with children of different age because there is too the small number of children and the decline in birth rates. The works of modern scientists about the researched problem are analyzed in the article. It is explained that the concept of "modeling» is broad and insufficiently concretized. It is established that the principles of modeling and planning specifically reflect, on the one hand, the principles of management, and on the other the features of planning as the preliminary stage and function of the management process. The author's model of professional training of future educators to the work in different age groups is based on the ideas of the personal activity, resource and integration approaches to pedagogical activity of students. The developed experimental model of the preparation of future educators for the work in different age groups covers the following components: purpose and tasks, approaches to pedagogical activity of students, stages, pedagogical conditions of the professional preparation of future educators for work in different age groups, indicators and levels.

It is said that the educational process must be based on the integration of the academic disciplines with the disciplines of methodological and practical training. The three stages of training future preschool education specialists are shown. The ways for the improving of the professional training of future educators to work with preschoolers in groups where there are children of different ages study are presented.
\end{abstract}

Key words: modeling, professional training, preschool education, age groups, the process of education.

Постановка проблеми. Модернізація системи дошкільної освіти спрямовує фахівців на пошук оптимальних шляхів особистісного розвитку дітей, розкриття механізмів формування їхньої життєвої компетентності як здатності в міру своїх вікових можливостей самостійно виробляти позитивне ставлення до самих себе, до оточення та до світу загалом.

Закони України «Про освіту» (2017), «Про дошкільну освіту» (2001), Базовий компонент дошкіль- ної освіти (2012) в Україні утверджують дитину як найвищу цінність. Так, у Законі «Про освіту» (2017) зазначається: «Метою дошкільної освіти є забезпечення цілісного розвитку дитини, iї фізичних, інтелектуальних і творчих здібностей шляхом виховання, навчання, соціалізації та формування необхідних життєвих навичок». Актуальність вивчення проблеми підготовки майбутніх педагогічних працівників у сфері дошкільної освіти до роботи з дітьми у різновіковій групі зумовлена стрімкою появою в останні роки закладів дошкільної освіти (даліЗДО) різних типів, зокрема приватних студій, виховних комплексів, центрів розвитку дитини тощо. Окрім того, сьогодні спостерігаємо процес укрупнення навчально-виховних установ та, відповідно, об'єднання груп у закладах дошкільної освіти. У сільській місцевості переважно функціонують різновікові групи, що зумовлено невеликою кількістю дітей та спадом народжуваності. Це спонукає заклади вищої освіти до підготовки фахівців, які працюватимуть у групах із дітьми різного віку.

Аналіз наукових досліджень і публікацій. Як засвідчує аналіз психолого-педагогічної літератури, в теорії дошкільної педагогіки досліджувалися передусім окремі аспекти змісту і форм педагогічного процесу в різновікових групах закладу дошкільної освіти. Так, наукові розвідки А. Арушанової, А. Давидчук присвячені вивченню педагогічних умов організації навчання дітей різного віку в спільній діяльності. У дослідженнях Н. Диновської, Г. Колосінської, Л. Русанви висвітлено основні форми організації та особливості педагогічного процесу з дітьми різного віку. Дослідниками Н. Губановою, Е. Кушнаренко, А. Михайловою розроблено модель освітньо-виховної роботи різновікової групи. У працях С. Литвиненко, М. Заячківської, I. Підлипняк проаналізовано теоретико-методичні підходи до професійної підготовки фахівців для роботи 3 дошкільниками різного віку.

Метою статті $\epsilon$ теоретичне обгрунтування структурних компонентів моделі підготовки майбутніх педагогічних працівників у сфері дошкільної освіти до роботи з дітьми у різновіковій групі.

Виклад основного матеріалу дослідження. Поняття «моделювання» $€$ широким і недостатньо конкретизованим. Різноманітні погляди на означену проблему знайшли відображення у працях як вітчизняних, так і зарубіжних учених. Дослідник Л. Капченко (2011) переконує, що принципи моделювання і планування специфічно відображають, з одного боку, принципи 
управління, а з іншого - особливості планування як попередньої стадії та функції процесу управління.

Погоджуємось із висновками О. Бернацької (2016) стосовно того, що «моделювання - це приблизне відтворення певних об'єктів, що через свою складність не піддаються чи погано піддаються дослідженню. Модель не тільки відрізняється від простого опису повнотою і точністю виявлених властивостей, а й $є$ цінним і надійним джерелом інформації про досліджуваний об'єкт. Імітаційне моделювання $є$ одним із засобів покращення навчання, а використання моделювання в освітньому процесі сприяє поглибленню знань 3 основ наук».

Зі свого боку В. Кузьменко (2016, с. 17) доводить, що моделювання - це опосередковане теоретичне або практичне дослідження об'єкта (середовища), завдяки якому безпосередньо вивчається не сам об'єкт, а певна допоміжна штучна або природна система. Натомість дослідник I. Підлипняк (2011, с. 193) підкреслює важливість психолого-педагогічного моделювання в сучасній системі педагогічної науки, адже саме завдяки моделюванню й педагогічному експерименту отримуємо сукупність інноваційних засобів, методів, методик і технологій педагогічної взаємодії, як-от: виховання, навчання, саморозвитку, самовизначення, самовдосконалення, самореалізації тощо.

Нами розроблено авторську модель професійної підготовки майбутніх вихователів до роботи у різновікових групах, що базується на ідеях особистісно-діяльнісного, ресурсного та інтеграційного підходів до педагогічної діяльності студентів ЗВО. Відповідно провідними принципами визначені: принцип свідомості й активності в навчанні; принцип системності навчально-пізнавальної діяльності; принцип послідовності й наступності, динамічності та поліфункціональності (див. рис.).

Представлена вище експериментальна модель підготовки майбутніх вихователів до роботи в різновікових групах включає такі складники: мета і завдання; підходи (особистісно-діяльнісний, ресурсний, інтеграційний) до педагогічної діяльності студентів; етапи (інформаційно-методичний, мотиваційний, практично-діяльнісний); педагогічні умови професійної підготовки майбутніх вихователів до роботи в різновікових групах; критерії (когнітивний, мотиваційний, операційний), показники та рівні (високий, середній, низький) підготовленості та діагностичний інструментарій.

Метою першого (інформаційно-методичного) emany було освоєння студентами інтегрованого об'єму науково-педагогічних знань, оволодіння знаннями 3 предметних методик та особливостей організації педагогічного процесу в різновіковій групі закладу дошкільної освіти. На цьому етапі було реалізовано першу педагогічну умову: побудова освітнього процесу на основі інтеграції навчальних дисциплін із дисциплінами методично-практичної підготовки, що необхідні у подальшій організаційній, творчій педагогічній діяльності майбутніх вихователів в умовах різновікової групи.

Для реалізації мети інформаційно-методичного етапу основним було визначено координоване використання міжпредметних зв'язків та інтеграцію змісту навчання. Відповідно було розроблено і впроваджено змістові модулі у зміст навчальних дисциплін «Педагогіка дошкільна», «Дитяча психологія», «Історія дошкільної педагогіки», «Теорія та методика формування елементарних математичних уявлень»,
«Методика ознайомлення дітей із соціальним довкіллям», «Комп’ютерні технології в роботі з дітьми», «Основи природознавства з методикою» та інші, при викладанні яких відбувалася актуалізація опорних знань студентів.

Ефективними формами та методами щодо реалізації мети було визначено: нестандартні лекції 3 використанням навчального матеріалу інтегративного характеру, семінарські заняття, самостійна робота творчо-пошукового характеру, методи активного навчання, дискусії-обговорення тощо.

На другому (мотиваційному) етапі основним завданням було формування у майбутніх педагогічних працівників у сфері дошкільної освіти настанови на взаємодію з різновіковим колективом дітей дошкільного віку; бажання працювати та прагнення вдосконалювати організацію педагогічного процесу в умовах різновікової групи закладу дошкільної освіти. На цьому етапі було реалізовано другу і третю педагогічні умови: моделювання навчальних ситуацій, спрямованих на засвоєння студентами специфіки роботи у різновіковій групі; поглиблення вмотивованості та особистісної спрямованості студентів на організацію різновікової взаємодії за рахунок упровадження у зміст освітнього процесу дисципліни «Навчання і виховання дітей у різновікових групах».

Під час проведення практичних та лабораторних занять активно використовувалося моделювання педагогічних ситуацій, самостійна робота творчо-пошукового характеру, робота в групах. Оскільки «важливим чинником формування професійної готовності майбутніх вихователів закладів дошкільної освіти до педагогічної творчості визначено креативність, яка як індивідуальна характеристика становить продуктивний аспект творчої особистості, що виражається в активній життєвій позиції, постійній спрямованості на творчу професійну діяльність» (Гаврилюк, 2016, с. 5), студенти активно працювали над виконанням завдань творчого рівня. На цьому етапі було розроблено і впроваджено у зміст навчальних дисциплін спеціальності 012 «Дошкільна освіта» курс «Навчання і виховання дітей у різновіковій групі», що побудований на принципі єдності теоретичної і практичної підготовки студентів - майбутніх вихователів закладів дошкільної освіти, який є складником загального процесу їхньої підготовки у ЗВО.

Метою третього (практично-діяльнісного) ета$n y$ стало набуття студентами практичного досвіду застосування теоретичних знань, умінь, навичок у ході педагогічної практики на засадах організації педагогічної взаємодії з дітьми різного віку та їхніми батьками. Педагогічною умовою, яка була зреалізована на цьому етапі, $є$ : опанування майбутніми вихователями системою компетентностей із проблеми освітньої діяльності у різновіковій групі та забезпечення практичної реалізації отриманих знань, умінь на навичок у середовищі закладу дошкільної освіти. Для реалізації мети практично-діяльнісного етапу в різновікових групах ЗДО було проведено педагогічну практику. Метою прикінцевого зрізу було виявлення ефективності розробленої експериментальної моделі підготовки майбутніх вихователів до роботи у різновікових групах закладів дошкільної освіти.

Таким чином, цілісне, системне уявлення про моделювання освітнього процесу ЗДО, що включало мету, завдання, підходи, принципи, етапи реалізації, методи, форми, педагогічні умови дає змогу на якісно 


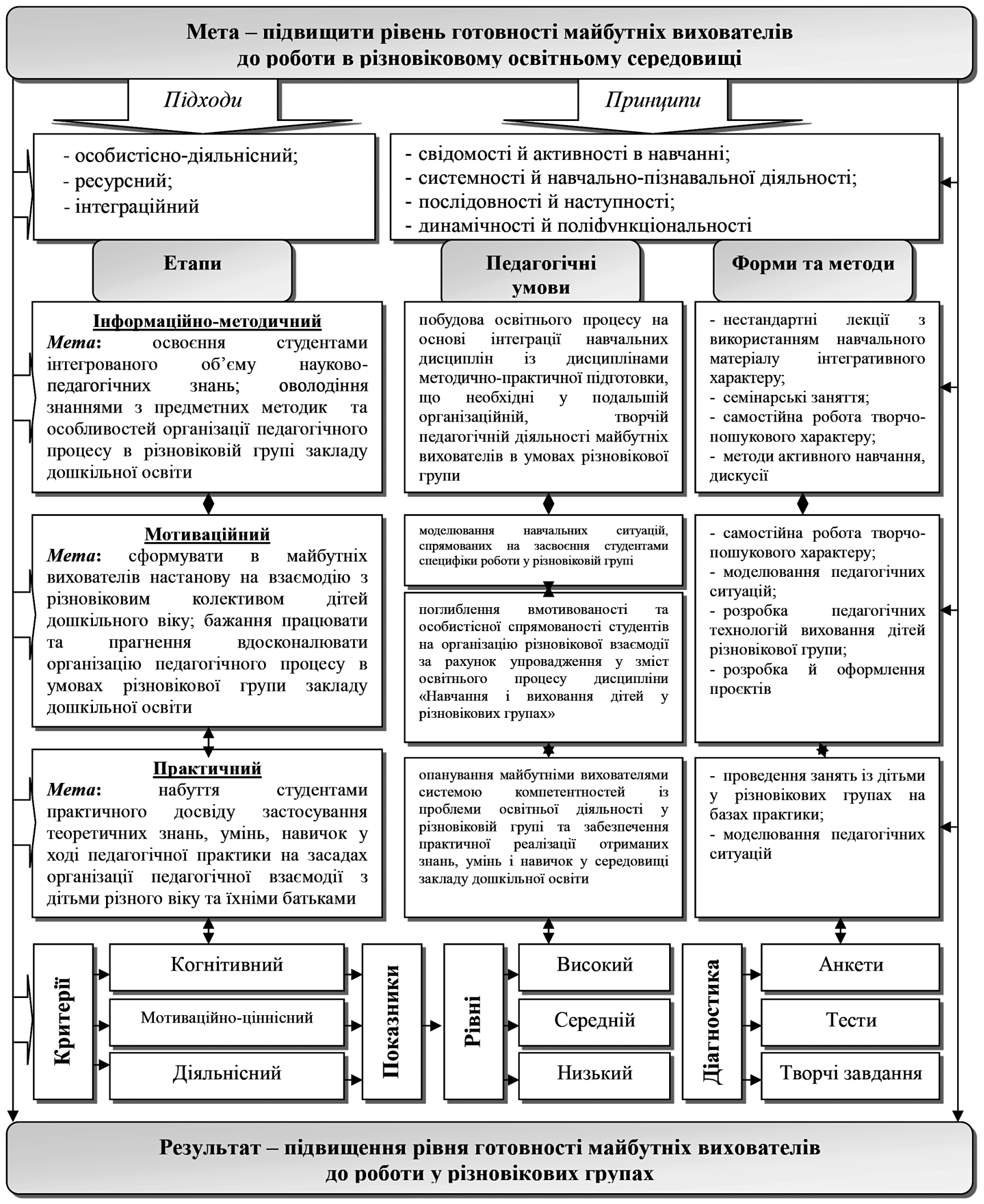

Рис. Модель підготовки майбутніх педагогічних працівників у сфері дошкільної освіти до роботи у різновікових групах

новому рівні організувати підготовку майбутніх педагогічних працівників у сфері дошкільної освіти до роботи з дітьми в умовах різновікового освітнього середовища закладу дошкільної освіти.
Висновки. Отже, авторська модель професійної підготовки майбутніх педагогічних працівників у сфері дошкільної освіти до роботи у різновікових групах базується на ідеях особистісно-діяльнісного, 
ресурсного та інтеграційного підходів до педагогічної діяльності студентів 3ВО та вміщує такі структурні компоненти: мета і завдання; підходи та принципи; етапи та педагогічні умови; критерії, показники та рівні підготовленості; діагностичний інструментарій. Завдяки моделюванню й педагогічному експерименту отримуємо сукупність інноваційних засобів, методів та форм підготовки майбутніх педагогічних працівників у сфері дошкільної освіти до роботи 3 дітьми у різновіковій групі.

Зважаючи на викладене вище, доцільним є вдосконалення підготовки майбутніх педагогічних працівників у сфері дошкільної освіти до роботи у різновікових групах дітей за такими напрямами: запровадження спецкурсу «Навчання і виховання дітей у різновіковій групі»; обов'язкове проведення педагогічної практики в різновікових групах; залучення студентів до самостійної роботи стосовно вирішення проблемами виховання дітей у різних вікових групах; залучення зарубіжного досвіду підготовки фахівців до роботи 3 дітьми в умовах різновікової групи.

Перспективи подальших досліджень убачаємо в дослідженні підготовки майбутніх педагогічних працівників у сфері дошкільної освіти до роботи в різновіковій групі з дітьми-представниками різних етнічних спільнот.

\section{СПИСОК ВИКОРИСТАНОЇ ЛІТЕРАТУРИ}

Про освіту: Закон України від 05.09.2017 р. № 2145-VIII. (2017). Відомості Верховної Ради. № 38-39. C. 380. URL: https://zakon.help/law/2628-III (дата звернення: 19.12.2020).

Про дошкільну освіту: Закон України від 11.07.2001 p. № 2628-III (2001). Відомості Верховної Ради України. № 49. C. 259. URL: https://zakon.rada.gov.ua/laws/ show/2628-14\#Text (дата звернення: 23.12.2020).

Базовий компонент дошкільної освіти. (2012). Київ: Видавництво. 26 с.

Капченко, Л. М. (2011). Педагогічні принципи моделювання планів роботи в професійно-технічних навчальних закладах. Сучасні інформаційні технологіі та інновачійні методики навчання в підготовиі фахівиів: методологія, теорія, досвід, проблеми. Вип. 27. C. $108-113$.

Бернацька, О. В. (2016). Особливості моделювання професійної діяльності у навчальному процесі. Навчально-методичний збірник. Київ: КІСВ. № 17. C. 68-74.

Кузьменко, Ю. В. (2016). Специфіка функціонування різновікових груп. Педагогіка та психологія. Вип. 52. С. 282-290.

Підлипняк, І. Ю. (2011). Професійна підготовка майбутніх вихователів до роботи $з$ дітьми в умовах різновікової групи: історія та сучасність. Наукові записки. Серія «Психолого-педагогічні науки» / Ніжинський державний університет імені Миколи Гоголя. № 5 . C. 192-195.
Гаврилюк, С. (2016). Теоретико-методичні засади професійної підготовки майбутніх вихователів дошкільних навчальних закладів до педагогічної творчості: автореф. дис. ... док. пед. наук: 13.00.04 / Уманський державний педагогічний університет імені Павла Тичини. 39 с.

\section{REFERENCES}

Pro osvitu: Zakon Ukrainy vid 05.09.2017 r. № 2145VIII [On Education: Law of Ukraine] (2017). Information of the Verkhovna Rada. № 38-39. S. 380. URL: https:// zakon.help/law/2628-III (data zvernennia: 19.12.2020). [in Ukrainian].

Pro doshkil'nu osvitu: Zakon Ukrainy vid 11.07.2001 r. № 2628-III [On Preschool Education: Law of Ukraine] (2001). Information of the Verkhovna Rada. № 49. S. 259. URL: https://zakon.rada.gov.ua/laws/show/2628-14\#Text (data zvernennia: 23.12.2020). [in Ukrainian].

Bazovyy komponent doshkil'noyi osvity [The basic component of preschool education] (2012). Kyiv: Vydavnytstvo. $26 \mathrm{~s}$.

Kapchenko, L. M. (2011). Pedahohichni pryntsypy modeliuvannia planiv roboty $\mathrm{v}$ profesiino-tekhnichnykh navchalnykh zakladakh [Pedagogical principles of modeling work plans in vocational schools]. Suchasni informatsiini tekhnolohii ta innovatsiini metodyky navchannia $v$ pidhotovtsi fakhivtsiv: metodolohiia, teoriia, dosvid, problemy. Vyp. 27. S. 108-113. [in Ukrainian].

Bernatska, O. V. (2016). Osoblyvosti modeliuvannia profesiinoi diialnosti u navchalnomu protsesi [Features of modeling professional activity in the educational process]. Navchalno-metodychnyi zbirnyk. Kyiv: KISV. Vyp. 17. S. 68-74. [in Ukrainian].

Kuzmenko, Yu. B. (2016). Spetsyfika funktsionuvannia riznovikovykh hrup [Specifics of functioning of different age groups]. Pedahohika ta psykholohiia. Vyp. 52. S. 282-290. [in Ukrainian].

Pidlypniak, I. Yu. (2011). Profesiina pidhotovka maibutnikh vykhovateliv do roboty $\mathrm{z}$ ditmy $\mathrm{v}$ umovakh riznovikovoi hrupy: istoriia ta suchasnist [Professional training of future educators to work with children in different age groups: history and modernity]. Naukovi zapysky. Seriya "Psykholoho-pedahohichni nauky» / Nizhynskyi derzhavnyi universytet imeni Mykoly Hoholia. Vyp. 5. S. 192-195. [in Ukrainian].

Havryliuk, S. (2016). Teoretyko-metodychni zasady profesiynoyi podhotovky maybutnikh vykhovateliv doshkil'nikh Navchal'nykh Zakladiv do pedahohichnoyi tvorchosti [Theoretical and methodological principles of professional training of future educators of preschool educational institutions for pedagogical creativity]: avtoref. dys. ... dok. ped. nauk / Umanskyi derzhavnyi pedahohichnyi universytet imeni Pavla Tychyny. 39 s. [in Ukrainian].

Дата надходження до редакиіï: 13.01.2021 p. 